\title{
PENGARUH PERASAN UMBI AKAR LOBAK (Rhapanus sativus $L$ ) TERHADAP PENINGKATAN KADAR PROLAKTIN DALAM DARAH MENCIT (Mus musculus) BETINA
}

\author{
Mas Loegito*, Paulus Liben ${ }^{\star *}$, Thin Soedarti ${ }^{\star \star *}$ \\ *UWK, **Fakultas Kedokteran Unair, ***FMIPA-Biologi Unair
}

\begin{abstract}
ABSTRAK
The objective of this research was to prove that the administration of radish tuber extract (Rhapanus sativus $\mathbf{L}$ ) to female mice (Mus musculus) might increase blood prolactin level. This was an experimental research using complete randomized design by involving three treatment groups and three control group, each with five replications. Materials consisted of radish tuber extract and 30 female mice of 8 weeks old divided into 6 groups, i.e., control groups of C1, C2, and C3, and treatment groups of T1, T2, and T3. C1, $C 2$, and C3 groups were given water of $1 \times 0.5 \mathrm{cc} /$ day per oral, $2 \times 0.5 \mathrm{cc} /$ day, and $3 \times 0.5 \mathrm{cc} /$ day respectively. Treatment groups of T1, T2, and T3 were given radish tuber extract of respectively $1 \times 0.5 \mathrm{cc} /$ day per oral, $2 \times 0.5 \mathrm{cc} /$ day, and $1 \times 0.5 \mathrm{cc} /$ day. Treatment was carried out for 21 days. Blood was subsequently taken from those rats for blood prolactin level. Data were analyzed using Anove test. If the results indicated significant difference of $95 \%(p=0.05)$, the analysis was continued with LSD. The conclusions of this experiment is the administration of radish tuber extract per oral may result in the increase of blood prolactin level.
\end{abstract}

Key words: blood prolactin level, female mice, radish tuber extract (Rhapanus sativus L)

\section{PENGANTAR}

Lobak (Rhapanus sativus L.) adalah tumbuhan yang termasuk famili Cruciferae, daun dan umbinya banyak digunakan sebagai sayuran (Heyne, 1987) dan juga digunakan sebagai obat batuk dan pelancar ASI (Anonim, 1993; Bambang, 1980; dan Manuhara, 1987). Kandungan umbi akar lobak berupa minyak atsiri, rafanol, dialil disulfida, saponin, pati, kalsium, vitamin A, B dan C, sedangkan daunnya mengandung protein lemak, kalsium, fosfor, besi, vitamin A dan C (Rismunandar, 1982; Sudarman dan Harsono, 1985).

Selain lobak mengandung zat progoitrin (2-hydroxy-3butenyl isothiocyanate) dan zat aktifator tioglikosidase dan myrosinase yang dapat mengubah progoitrin menjadi goitrin (5-vinil-2-tiooksazolidin). Zat aktifator tersebut tidak tahan panas, tetapi di dalam usus terdapat bakteri yang dapat menghasilkan glikosidase yang dapat mengubah progoitrin menjadi gotrin (Ganong, 1999; Williams, 1981; dan Goodman and Gilman, 1970). Goitrin (5-vinil-2tiooksazolidin) yang merupakan zat goitrogen aktif, yaitu suatu zat yang dapat menyebabkan goiter (pembengkakan kelenjar tiroid) (Turner and Bagnara, 1988; Ganong, 1999).

Kelenjar tiroid adalah sepasang kelenjar hormon yang terletak di daerah leher di masing-masing sisi dari trakhea. Kelenjar tiroid menghasilkan dua macam hormon yaitu L. tiroksin (levotiroksin $=\mathrm{T} 4)$ dan triiodotironin (liotironin = T3) (Mutschler, 1991). Berdasarkan fungsi tiroksin dan triiodotironin tersebut pada dasarnya mempunyai sifat sama, tetapi kecepatan dan intensitas kerjanya berbeda.
Triiodotironin berpotensi empat kali lebih cepat daripada tiroksin, tetapi kadarnya di dalam darah sangat sedikit dan dalam waktu yang singkat bila dibanding dengan tiroksin (Guyton and Hall, 1996).

Kekurangan hormon tiroid (hipotiroksin), khususnya hipotiroidisme primer menyebabkan kadar thyroxin releasing hormone (TRH) endogen dan thyroxin stimulating hormone (TSH) meningkat. Hal ini disebabkan oleh bertambahnya kepekaan hipofise pada keadaan hipotiroksin. TRH akan merangsang sel-sel laktotrof pada hipofise anterior untuk mensintesis prolaktin. Meningkatnya kadar prolaktin menyebabkan hipotiroksin yang akan menghambat sekresi FSH dan LH, sehingga mengganggu proses pematangan folikel dalam ovarium (Wiknjosastro dan Saifudin, 1977).

Karena lobak mengandung goitrin (5-vinil-2tiooksazolidin) yang dapat menghambat monoiodotiroksin (MIT) dan diiodotiroksin (DIT), sehingga produksi T3 (Triiodotironin) dan T4 (tetraiodotironin atau tiroksin) terhambat dan kadarnya di dalam darah pun akan menurun (William, 1981). Dan dengan turunnya kadar tiroksin darah (hipotiroksin) akan menyebabkan hipotalamus mensekresi TRH yang akan merangsang hipofise bagian anterior untuk mensekresi TSH lebih banyak, selain itu TRH juga akan merangsang sel laktotrof untuk mensintesis prolaktin.

Maka, berdasarkan hal di atas, kami ingin mengetahui pengaruh perasan umbi akar lobak terhadap peningkatan kadar prolaktin dalam darah mencit betina. 


\section{BAHAN DAN CARA KERJA}

\section{Bahan Penelitian}

Perasan umbi akar lobak (Rhapanus sativus L.) yang diperoleh dari desa Tegalwaru, Dau-Malang; mencit (Mus musculus starin BALB-C) betina umur 8 minggu dengan berat badan 20-30 gr dari Lab. Biokimia FK Unair Surabaya; makanan ternak HI-PRO-VITE-medicated no. 593, produk PT Karina-Surabaya; Aquabides; bahan kimia untuk membuat sediaan mikroteknik ovarium; reagan kit untuk prolaktin (TRG. Prolactin DPC USA).

\section{Cara Kerja}

\section{Pengelompokan dan Perlakuan Hewan Uji}

Hewan uji dikelompokkan menjadi 6 kelompok perlakuan yaitu kelompok perlakuan $\mathrm{P}_{1}, \mathrm{P}_{2}$, dan $\mathrm{P}_{3}$ masingmasing terdiri atas 5 ekor mencit dan diberi $0,5 \mathrm{ml}$ perasan umbi akar lobak satu kali per hari $\left(\mathrm{P}_{1}\right), 0,5 \mathrm{ml}$ perasan umbi akar lobak dua kali per hari $\left(\mathrm{P}_{2}\right)$, dan $0,5 \mathrm{ml}$ perasan umbi akar lobak 3 kali per hari $\left(\mathrm{P}_{3}\right)$. Sedangkan 3 kelompok yang lain sebagai kelompok kontrol $\left(\mathrm{K}_{1}, \mathrm{~K}_{2}\right.$, dan $\left.\mathrm{K}_{3}\right)$ masingmasing terdiri dari 5 ekor mencit yang hanya diberi $0,5 \mathrm{ml}$ aquabides satu kali per hari $\left(\mathrm{K}_{1}\right), 0,5 \mathrm{ml}$ akuabides dua kali per hari $\left(\mathrm{K}_{2}\right)$, dan $0,5 \mathrm{ml}$ akuabides 3 kali per hari $\left(\mathrm{K}_{3}\right)$.

\section{Pengambilan serum dan ovarium mencit}

Setelah 21 hari mencit diambil darahnya untuk diperiksa kadar prolaktinnya. Serum darah dipisahkan berdasarkan metode Jonstone dan Thorpe, kemudian serum disimpan dalam Eppendorf, dan disimpan dalam suhu $-30{ }^{\circ} \mathrm{C}$ sebelum dianalisis.

\section{Pemeriksaan prolaktin dalam darah mencit}

Pemeriksaan prolaktin dalam serum darah menggunakan metode "Ria Fase Padat" dengan tahapan sebagai berikut.

a. Labelling semua tube-kit prolaktin dari semua standar dan sampel.

b. Memasukkan kalibrasi dari sampel masing-masing $200 \mu 1$.

c. Penambahan kit prolaktin $1000 \mu 1$.

d. Pengocokan dilakukan dengan menggunakan for texer selama satu menit dengan menggunakan thermolyne (type 37600 mixer).

e. Sampel ditaruh dalam suhu kamar selama 18 jam untuk memungkinkan terjadinya pengikatan antigen-antibodi.

f. Pembuangan dan penyerapan sisa limbah zat radio aktif dengan cara membalikkan tube di atas kertas tissue selama 3-5 menit.

g. Kemudian sampel ditera dengan instrumen GamaCounter-Mini Assay (type 6-80). h. Hasil peneraan dimasukkan ke dalam tabel Assay Identification.

i. Penentuan kadar prolaktin serum darah mencit didasarkan pada Ceaire - Sorin Logit log paper for linearization of the radioimmunoassay standard curve.

\section{Analisis Data}

Data diperoleh berupa kadar prolaktin dari masingmasing mencit dari tiap kelompok, kemudian dibandingkan kadarnya antar kelompok.

Analisis data berdasarkan Analysis of Variant (Anova) dilanjutkan dengan uji Beda Nyata Terkecil (BNT).

\section{HASIL DAN PEMBAHASAN}

Pada penelitian ini, data hasil pengukuran kadar prolaktin darah mencit disajikan pada Tabel 1. Dan data kadar prolaktin darah tersebut diuji dengan uji Anova yang disajikan pada Tabel 2.

Tabel 1. Rerata kadar prolaktin darah mencit betina

\begin{tabular}{ccc}
\hline No. & Kelompok & Rerata kadar prolaktin darah $\mathbf{( m g} \mathbf{m} \mathbf{m})$ \\
\hline 1 & $\mathrm{P}_{1}$ & $19,8 \pm 5,7$ \\
2 & $\mathrm{P}_{2}$ & $22,3 \pm 4,6$ \\
3 & $\mathrm{P}_{3}$ & $19,9 \pm 1,7$ \\
4 & $\mathrm{~K}_{1}$ & $1,7 \pm 1,0$ \\
5 & $\mathrm{~K}_{2}$ & $1,0 \pm 1,0$ \\
6 & $\mathrm{~K}_{3}$ & $1,6 \pm 1,0$ \\
\hline
\end{tabular}

Keterangan: angka yang diikuti huruf yang sama berarti tidak ada beda nyata

Tabel 2. ANOVA untuk kadar prolaktin darah

\begin{tabular}{lrrrcc}
\hline $\begin{array}{c}\text { Sumber } \\
\text { Variasi }\end{array}$ & $\begin{array}{r}\text { Jumlah } \\
\text { Kuadrat }\end{array}$ & df & $\begin{array}{r}\text { Kuadrat } \\
\text { Tengah }\end{array}$ & F & $\begin{array}{c}\text { Pro- } \\
\text { babilitas }\end{array}$ \\
\hline Antar kelompok & 2786,252 & 5 & 557,250 & 55,679 & 0,000 \\
Galat & 240,200 & 24 & 10,008 & & \\
\hline Total & 3026,452 & 29 & & & \\
\hline
\end{tabular}

Dari hasil uji Anova tentang perbedaan jumlah kadar prolaktin darah mencit antara kelompok perlakuan dengan kelompok kontrol diperoleh nilai probabilitas lebih kecil dari 0,05 (Tabel 2). Hal tersebut menunjukkan bahwa perasan umbi akar lobak pada mencit sangat berpengaruh terhadap peningkatan kadar prolaktin darah mencit. Hal tersebut sesuai dengan pendapat Turner and Bagnara (1988) dan Wiknjosastro dan Saifudin (1997) yang menyatakan bahwa kandungan 5-vinil-2-tiooksazoidin dalam lobak dapat menyebabkan turunnya produksi tiroksin. Sedangkan turunnya kadar tiroksin darah akan menyebabkan naiknya kadar TTSH darah yang akan menstimuli sel-sel laktotrop pada hipofise anterior untuk memproduksi prolaktin berlebihan. 
Dari hasil uji LSD 5\% tentang kadar prolaktin darah antara kelompok perlakuan P1, P2, dan P3 diperoleh nilai probabilitas lebih besar dari 0,05 berarti kadar prolaktin darah mencit antara kelompok P1, P2, dan P3 tidak terdapat perbedaan yang bermakna, sehingga dapat disimpulkan bahwa besarnya volume perasan umbi akar lobak tidak berpengaruh terhadap peningkatan kadar prolaktin di dalam darah mencit betina.

\section{SIMPULAN}

Berdasarkan hasil penelitian dan pembahasan, dapat ditarik kesimpulan bahwa sebagai berikut. Bahwa ada perbedaan yang sangat signifikan peningkatan kadar prolaktin dalam darah mencit betina yang diberi perasan umbi akar lobak dengan yang tidak diberi. Sedang, peningkatan besarnya volume perasan umbi akar lobak tidak berpengaruh terhadap peningkatan kadar prolaktin dalam darah mencit betina.

\section{KEPUSTAKAAN}

Anonim, 1993. Pemanfaatan Tanaman Obat (Edisi 3). Penerbit Direktorat jendral Pengawasan Obat dan Makanan Depertemen Kesehatan Republik Indonesia.
Bambang S, 1980. TOGA. DepKes-RI.

Ganong, William F, 1999. Review of Medical Physiology, nineteenth edition, Appleton \& Lange, Stamford Conecticut.

Goodman LS and Alfred Gilman, 1970. The Pharmacological Basic of Therapeutic, Fourth Edition, The Mc Millan Company, London.

Guyton AC and Hall John E, 1996, Textbook of Physiology, WB. Saunders Company, Phyladelphia - London - Toronto Tokyo.

Manuhara YSW, 1987. Pengaruh Pemberian Perasan Umbi Akar Lobak (Rhapanus sativus, L) terhadap Gambaran Histologis Kelenjar Susu Mencit (Mus musculus) yang Menyusui. Skripsi FMIPA. Universitas Airlangga. Surabaya.

Mutscher, Ernt, 1991. Dinamika Obat. Buku Ajar Farmakologi dan Toksikologi edisi ke-5. Penerbit ITB Bandung.

Rismunandar, 1982. Bertanam sayur-sayuran, Cetakan ke-6, Penerbit Terate, Bandung.

Sudarman M dan R Harsono, 1985. Cabe Puyang Warisan Nenek Moyang I, PN Balai Pustaka, Jakarta.

Turner C, Donnell, and Joseph T Bagnara, 1998. Endokrinologi Umum, Edisi ke-6, Airlangga University Press.

Wiknjosastro H dan Abdul Bari Saifudin, 1997. Ilmu Kandungan. PT. Gramedia. Jakarta.

William, Robert H, 1981. Textbook of Endocrinology, Sixt Edition, WB Saunders Company, Phyladelphia - London - Toronto.

\author{
Reviewer: Tim Reviewer \\ Seminar Biologi Nasional tahun 2005 \\ Surabaya
}

